\title{
Nostalgia, Nationhood, and the New Immigrant Narrative: Gary Shteyngart's The Russian Debutante's Handbook and the Post-Soviet Ex- perience
}

\author{
Natalie Friedman
}

A vanguard of young post-Soviet authors who immigrated to America over the past thirty years are now documenting their experiences of dislocation and deracination as they navigate not two but three cultures: the Soviet Union of their youth, their adopted nation of America, and the new post-perestroika Republics that have replaced the former Soviet Union. As these writers evoke these discrete political and physical spheres, they engage the idea of nostalgia as a means by which to combat the strong pressure to assimilate to American culture. In these works of semiautobiography, such as Gary Shteyngart's The Russian Debutante's Handbook (2002), Lara Vapnyar's There Are Jews in My House (2003), and David Bezmozgis's Natasha: And Other Stories (2004), America is characterized as a land of antinostalgia or anti-memory. Its culture of upward mobility and promise of economic success conspire to repress the immigrant's memories of home. In a radical reversal of the tropes of classic immigrant literature, these narratives present characters who resist assimilation through nostalgia, but who also fall victim to their own fantasies of their former homelands when they return or otherwise encounter their old culture. In their peripatetic narratives, these characters destabilize the notion of Americanization and revise the idea of a genre of assimilation narratives within the subset of American ethnic writing.

Characters in the growing post-Soviet oeuvre often sample the consumer prod-

Natalie Friedman teaches English at Vassar College, where she is also co-director of the Writing Center. Her academic interests include nineteenth- and twentieth-century American literature, ethnic American and global literatures, and writing pedagogy. She is currently working on a project concerning nostalgia in immigrant narratives. 
ucts designed to help ease them into American success - abundant food, suburban homes, drugs - but they find little pleasure in these ephemera. Their real pleasure is derived from remembering, reminiscing, or even vicariously reliving moments from their childhood or their homeland. In Vapnyar's story "Broccoli," for example, a young Soviet immigrant purchases vegetables that seem wonderfully exotic and American and then hesitates to prepare them because of their unfamiliarity. In Bezmozgis's story "Natasha," the adolescent immigrant narrator, though Canadian, experiences the typical summer of a bored, middle-class boy anywhere in America: he sits by his friend's pool and smokes pot while developing a dangerous crush on a young Russian girl, who embodies his memories of the Soviet experience he left behind as a boy.

These stories demonstrate America's power to blunt the pain of immigration by creating an alternate reality to the one experienced by the central characters in their native lands. The consumer comforts of a capitalist state serve to distance the characters from their old cultures. A brush with the homeland, however, has the effect of jolting them out of their newly acquired American complacency. In the case of Bezmozgis's collection, the main character Mark's encounter with a lovely and perverse Russian girl becomes the antidote to his soporific North American life and reminds him that he, too, is an outsider. Shteyngart's novel exemplifies this conflict between American anti-memory or complacency and Russian nostalgia. His protagonist, Vladimir Girshkin, indulges in nostalgic recollections of his youth in Russia and longs to escape the stranglehold of American consumerism, even as he desires to become wealthy and successful. He therefore decides to return to Eastern Europe in a bid to rediscover the lost culture of his youth and simultaneously make a fortune on the ruins of the Communist system. He exchanges his status as "immigrant" for that of a sojourner - a temporary resident, a visitor. In his nostalgia for the past, he is typical of older immigrant literary prototypes, but in his round-trip journeys and his conflicting desires for wealth and a rejection of American antimemory, he is entirely new. As Nicholas Dames writes in his study of memory and the Victorian novel, nostalgia "is a disease of failed assimilation-of psyches whose geographical, political, social and constitutional barriers to frequent encounters with new stimuli create an inability to adapt" (31). Due to the fact that characters in an immigrant novel can (and do) cross borders that have become permeable, they are constantly creating psychological barriers that do not allow them to adapt; rather, they act in ways that indulge their nostalgia, be it through return or through their rejection of American ideals of class mobility.

Nostalgia is not new to immigrant narratives, but the way in which it functions in literature by contemporary post-Soviet writers hails a change in the Americanization narrative. The classic tales of Americanization-those written at the end of the nineteenth or the beginning of the twentieth century-contain scenes and moments in which characters confess their homesickness and desire to return; however, the details of their realist plots-factory work, tenement poverty, English education-leaves them little time and room for nostalgic reminiscing. Immigrant characters in these classic texts rarely recall the past once they arrive in America. These characters cannot indulge their homesickness because they must cut them- 
selves off entirely from their lost culture-assimilation becomes abandonment. This notion is reinforced by the writers' inability to return to their native lands, even for a visit. Novels and memoirs such as Abraham Cahan's The Rise of David Levinsky and Mary Antin's The Promised Land suggest that the immigrant sought to assimilate and erase the past, converting wholeheartedly to an American way of life. Indulging in nostalgia was therefore a barrier to acculturation.

Mary Antin's 1912 memoir The Promised Land describes the Antin family's journey from Russia to America at the turn of the twentieth century, a trip she calls "The Exodus," implying, by the evocation of the Biblical book of Exodus, a journey out of a land of bondage to which one will never return. Non-return was an experience common to Eastern European Jewish immigrants (and the Irish), who wrote about the inability to return in their diaries, letters, and fiction. These immigrants came to America to stay; they had no intention of returning to homelands that were loci of poverty, starvation, abuse, and violence. Antin says that when, as a young immigrant, she sang the words of the "Star-Spangled Banner," she felt "delicious tremors" run up her spine, thinking with relief that she now had a country and a flag to love (178).

In newer works, such as Shteyngart's, the immigrant character does not have to view Americanization as a definitive, totalizing act-nor does he want to do so. He can remain ambivalent about his status in America without fully embracing acculturation the way Antin did. Shteyngart's protagonist is indeed a self-proclaimed "beta immigrant," a second-class citizen who has not been able to realize the "American Dream" of wealth and personal success. He therefore feels nostalgic for Russia and his feelings of homesickness are compounded by the seductive ability to return or to travel back and forth between his home of origin and his adopted home. Shteyngart is also less concerned with representing realist details of immigration and assimilation; his novel resembles, and pays homage to, political satires such as Jonathan Swift's Gulliver's Travels, Valdimir Nabokov's Invitation to a Beheading, or Mikhail Bulgakov's The Master and Margarita. Inasmuch as immigrant narratives form a tradition within ethnic American literature, one can say that Shteyngart's work signals a departure from the accepted tropes and traditions of the immigrant novel in America because it is an absurd story about travel, international crime, and post-national accommodation more than it is about Americanization.

William Boelhower, who attempted to define the immigrant narrative by its various narratological devices, recognized certain patterns in immigrant autobiography that reappear in various guises. He describes each immigrant autobiography as a "microtext" within a larger "macrotext" of American history and self-perception. These microtexts bear the same narrative constants: each begins with a moment of "dream anticipation," which is then followed by a period of transformation and confirmation, variation, negation, and substitution of the codes of the dominant culture (20). He noticed that almost all autobiographies begin in the Old World and then follow the protagonists on their journey to the New, where they confront the clash of two systems and adjust or suffer accordingly.

Older immigrant narratives-both autobiographies and novels from the late nineteenth or early-twentieth century in America-cleave quite closely to 
Boelhower's model. Mary Antin's memoir, for example, is a traditional immigrant narrative: it begins in the homeland, documents the journey to America, and then explores the assimilation of its characters to American culture without once looking back. Shteyngart retains some of the recognizable marks of the immigrant narrative, but he also disrupts the conventions. The traditional motifs of Old World and New World, of the journey to America and the journey within America, are radically altered in this newer narrative and are replaced instead with a kind of fluidity, which also underscores the postmodern flexibility of identity and national consciousness. His narrative begins in New York City-the dominant locus of immigrant discourse in America and the city to which many immigrant protagonists make their way - and then follows his Russian-born hero back to Eastern Europe for a brief stint. The plot then follows Vladimir back to the United States, where he relocates to the literal center of America: the Midwest. The Midwest stands in contrast both to the Old World in Europe and the Old World in New York: whereas New York is coastal/marginal, Ohio is central; whereas New York is home to the thousands of "tempest tossed" multitudes who have sought American refuge, Ohio is home to "authentic" or more assimilated Americans.

In the opening pages of the novel, the narrator describes Vladimir as "the immigrant's immigrant, the expatriate's expatriate," and this conjunction of words signals the central conflict of the novel (1-2). Vladimir is technically an immigrant, but following closely upon that label comes the word "expatriate," which hints at a more temporary arrangement than immigration. The word "expatriate" foreshadows Vladimir's immanent trip back to Eastern Europe, where he finds himself in a simulacrum of his past experiences. His return is not a homecoming, but a change in status-from immigrant to expatriate. Furthermore, the etymology of the word "expatriate" complicates Shteyngart's usage-the verb "to expatriate" comes from the Latin expatriare and has both the meaning "to banish" but also "to withdraw from one's native country." Shteyngart then uses the word self-consciously to differentiate the idea of banishment/withdrawal from the more political word "immigration."

The change in self-fashioning from "immigrant" to "expatriate" is a linguistic and ideological difference that can be attributed to the changes immigrants themselves have undergone. The immigrant today is no longer only and always a refugee who can never go back; similarly, the United States is no longer simply a space or zone of safety. As Arjun Appadurai writes in Modernity at Large, the United States is now part of a constantly shifting "ethnoscape" or "landscape of persons who constitute the shifting world in which we live: tourists, immigrants, refugees, exiles, guest workers, and other moving groups" (33). To expatriate oneself could be seen as an act of personal agency rather than the result of desperate need for political asylum: one has decided to leave his land.

In reversing the traditional movement from Old World to New, Shteyngart also inverts the usual assimilation experience. Vladimir no longer has to assimilate to American culture but to Eastern European life. He decides to "repatriate" himself in an effort to find a middle ground between the disappointment and disillusionment of American assimilation and the oppression of the past: "In fact, he would never be an immigrant again, nevermore a man who couldn't measure up to the natives. From 
this day forward, he was Vladimir the Expatriate, a title that signified luxury, choice, decadence, frou-frou colonialism" (170). Here, the word "expatriate" (capitalized to show its positive connotations) clearly does not mean "one who is banished" nor even "one who has withdrawn from his native land." Rather, the term applies to someone who has chosen to move to a foreign country to live out a glamorous ideal. Whereas in America assimilation meant forgetting his Soviet past and struggling for American-style consumerism and upward mobility, in the new Eastern Europe it means achieving outrageous economic success, even if it means kowtowing to a criminal underclass or a colonialist, exploitative system.

The now-defunct Soviet empire once expelled thousands of people who grew up under the Soviet regime and who knew they could never return, but this is not the case today. Svetlana Boym, a Soviet immigrant herself, divides Soviet migrants into two categories: those who left during the glukhaia emigratsiia or "deaf emigration" period from 1972-1987 and those who are emigrating post-perestroika. Those who emigrated during the "deaf" period under the "family reunification" clause that the U.S.S.R. recognized after the Helsinki Agreement are, according to Boym, "uniquely unsentimental: theirs was an old-fashioned exile without return" (329). These naturalized Americans do not want to return because, as Boym writes, "[ $\mathrm{t}$ ]he experience of that first border crossing that put a taboo on a backward glance was a watershed for them, a trauma that they refused to sentimentalize or even dwell on" (331). In contrast, post-perestroika immigrants are welcome to go back and forth with greater freedom than ever allowed during the time of the Iron Curtain, and unlike the immigrants of the "deaf" period they do sentimentalize their old nation.

Vladimir is an example of the newer Soviet immigrant. Not only can he travel back and forth between his old and new continents, he also enjoys indulging in melancholy memorializing of the past. He enjoys remembering, for example, how his grandmother would take him to the grave of his grandfather, who fought alongside the Russians against the Germans in the battle of Leningrad. In his memories of Russia, his grandmother ensures him that he will make an excellent "Red Pioneer"a member of the youth group designed to inculcate youngsters into the Communist Party. Vladimir recalls the scenes with his grandmother fondly and compares them with his jarring arrival to the United States:

In the end, in the late 1970s, to be exact, the gentle, toothy American Jimmy Carter swapped tons of Midwestern grain for tons of Soviet Jews, and suddenly Vladimir and Grandmother found themselves walking out of the International Arrivals building at JFK. They took one look at the endless America humming her Gershwin tune before them and cried in each other's arms. (38)

Shteyngart's characterization of Vladimir's Communist youth and the conflicting image of a Whitmanian swath of America "humming her Gershwin tune" is, of course, ironic. The fact that Vladimir and his grandmother were fond of Russia and its culture of Communism was due, in large part, to indoctrination and brainwashing, but the narrator of the novel suggests that America has a way of undoing the Soviet brainwashing with its own brand of propaganda. The difference is that the propaganda of the United States is proffered to the tune of a Gershwin song, a song 
written by a Russian Jewish immigrant and one that promises financial success, personal fulfillment, and a stable home life. American theories of nationhood had to do with a looking forward, an optimism that nostalgia undermines, as Michael Kammen points out:

\begin{abstract}
Nostalgia was perceived as a European disease. Hence nations that came of age late and wished to distinguish themselves from aging Europe developed their identity on an antinostalgic premise; for better or worse they claimed to have managed to escape the burden of historical time . . . . Early nineteenth century Americans perceived themselves as "Nature's Nation," something that lives in the present and has no need for the past-what Jefferson called the "blind veneration of antiquity, for customs and names to overrule the suggestions of our own good sense." (qtd. in Boym 16)
\end{abstract}

Here one can see the seductive Jeffersonian ideal of American anti-nostalgia and how it stands in stark contrast to Vladimir's desires, which are reflexively, almost inherently, nostalgic. His constant recollection of childhood memories is exacerbated by his inability to be a successful immigrant in America, which further serves to make him yearn for the past and for an escape from American anti-nostalgia.

Nostalgia, a term coined from the Greek nostos (return home) and algia (longing), was originally a medical illness diagnosed in the seventeenth century by the Swiss doctor Johannes Hofer for those suffering from a severe longing for home and from the symptoms that resulted from that longing, such as asthma and depression (Dames 29). In the twentieth century, nostalgia has come to mean more than the physical symptoms of homesickness; it has become a metaphor for the ambivalent immigrant, the inassimilable immigrant, or even the anti-assimilationist immigrant. Today's nostalgic is, according to Boym, "a displaced person who mediates between the local and the universal" (15). In her characterization of nostalgia as a condition in which a person moves between the poles of local/individual and universal/collective, Boym suggests a polarization between place of residence and place of origin, thereby creating the imagined feeling that the place of residence is not really "home"-home is someplace far away. Nostalgia becomes more than just a longing for the familiarity and comfort of home; it is sense of having lost ties to a nation and a national identity.

According to Fredric Jameson, nostalgia has also become a formal or generic marker-a way of processing or accessing the past through a contemporary representation of the past. He calls this development "nostalgia for the present" and suggests that films of the late 1980s strove to recapture the glamour of early "gothic" films but that the encasing of the earlier genre in contemporary fixtures leeches the historicity out of the original film genre (526). Nostalgia, therefore, is both substantive and stylistic: it is both a longing for the past experienced by the immigrant writer/character and a stylized representation of pastness.

New immigrant literature engages nostalgia in the Jamesonian sense as well as in its thematic rendering of the polarization Boym describes. Shteyngart's novel in particular is interested in representing Eastern Europe-the writer's place of origin-as a failed nostalgic reconstruction of the U.S.S.R. Jameson, in his discussion 
of the science fiction writer Philip K. Dick's nostalgic evocation of the 1950s, suggests that the representation of an era is inherently revisionist and therefore has no claim on reality (517). Shteyngart's novel points up this idea. In certain scenes in the novel where Vladimir recalls his Soviet childhood, the past seems to resemble realist depictions of Soviet life. The twist, however, is that when Vladimir goes to Eastern Europe as an adult, he enters an Eastern Bloc Anywhere that is not realist in any strict sense. In fact, the scenes in Eastern Europe are pure satire, bordering on the absurd. One could say that the descriptions of his fictionalized European city are nostalgic representations, not for pre-perestroika Communism but for the chaos inaugurated after the fall of the Berlin Wall in 1989, when Eastern Europe itself became polarized and a nostalgia for the pre-Communist past gave rise to revolutions. In one scene, for example, Vladimir stumbles upon a political rally taking place at "the Foot," the remains of an oversized statue of a former tyrant. "The Foot" becomes an absurdly satiric reminder of the oppressive regime about which many of the Eastern European characters feel nostalgic.

Shteyngart's narrative even goes so far as to suggest that there is no such thing as a "realist" representation of life in post-Communist Eastern Bloc countries; as he sees it, life in Russia before or after Communism bordered on absurdism. His satire therefore exaggerates those aspects of Soviet and post-Soviet life that seem most at odds with American culture: the black market, mob violence, and revolutionary proletarians fighting for a vague political idea of "freedom." Furthermore, his narrative capitalizes on the American desire for Eastern Bloc authenticity: in addition to being the story of one immigrant, The Russian Debutante's Handbook is a cynical look at the American craze for Eastern Europe in the early 1990s, shortly after the collapse of the Berlin Wall.

The novel recreates the American fascination with post-Communist Eastern Europe, as hundreds of young Americans flocked to Eastern capitals once closed to them, in search of a sentimental ideal. The city in Shteyngart's novel, Prava, is the fictitious capital of a fictional post-Soviet satellite country called Stolovaya, and it is a satiric reconstruction of Prague in the 1990s, a place of cheap beer and slightly sleazy economics. Prava is often referred to in the novel by various characters as the "Paris of the Nineties," a phrase that captures the essence of nostalgia. It is the second half of an analogy-Prava is to the 1990s as Paris was to the 1920s or the 1950s: fill in the blanks with whatever nostalgic image one has of Paris. Which Paris do the characters desire? Perhaps pre-World War II Paris, filled with modernist painters, cubists, and poets? Perhaps post-war Paris, with Bardot, Godard, and Truffaut capturing images of bleakness mixed with optimism and romance? Prava comprises all of these images: it is a decaying European city, with its ugly Soviet-era buildings and crumbling statues of Lenin, but it is also a hotbed of cultural activity stimulated by the influx of American tourist money and bohemian interest.

Prava is, in short, an example of the filmic nostalgia that Jameson describes: it evokes an American's idea of what an Eastern Bloc city looks like. It is a simulacrum of a European city. It is an American consumer's vision of Eastern Europe's past, not an actual representation of that past, and therefore it provides the antidote to American anti-memory that Vladimir and the few bored, idealistic, worldly Ameri- 
cans he meets seek.

The American desire to escape memory is represented in the novel by New York. New York is the symbolic opposite to Prava. It is home to a mingling mass of immigrants, both new and old, assimilated and unassimilated, but all intent on the same dream. The novel opens, in fact, at the comically named "Emma Lazarus Immigrant Absorption Society," where, as the narrator describes it, Hutus and Tutsis rub shoulders without incident (2-3). The Society, where Vladimir works a thankless administrative job, is a microcosmic symbol of New York's constant influx of immigrant energies and the forward drive towards assimilation.

Shteyngart's New York is also home to a group of American intellectuals who are so bourgeois as to want to escape memory entirely; these intellectuals are embodied in the character of Francesca Ruocco, Vladimir's love interest in the first half of the novel. Francesca and her parents are wealthy, Fifth-Avenue intellectuals who are distanced from their own immigrant pasts. Francesca's father, a history professor at City College, demonstrates the anti-nostalgia and anti-history of Americans; as Francesca tells Vladimir, Professor Ruocco is the founding member of a new department of Humor Studies: "He's starting a whole new field. Evolving a whole new field, I should say. It's called Humor Studies. Its better than brilliant; it's thoroughly unexpected! And he has New York's two million Jews at his disposal" (82). The Ruocco's obsession with the new-a new department, a new field-and their obsession with humor over history serves as an example of anti-nostalgia. They are not homesick because America is their home, they have no need for the past because it serves only as a source for humorous anecdotes, and they feel no compunction at singling out Jews as an ethnic group because they do so in order to serve their own purposes. When Francesca unwittingly mocks Vladimir's accent, he recognizes her disrespect for the past and for his own individual traumas, his desires to "fit in."

In contrast, Prava, the nostalgic Eastern European Paris, is a place where young Americans come to live out fantasies of being like Hemingway and Fitzgerald with a post-Communist twist. They sit in cafes and write bad poetry or they get involved with local revolutionaries who are mobilizing to restore the Old Order. In an attempt to discover some sort of past, they latch on to the memories of recently vanquished Communism. Vladimir quickly finds ways of asserting his post-national identity in this atmosphere. Neither American nor Russian, but a bit of both, he slides comfortably into two cultures: that of the expatriate American artist-and-writer's scene and the Russian-run mafia scene. In doing so, he achieves economic success and a degree of fame. By returning to Europe, Vladimir wins the success he dreamed of in America, because in the New Europe there is no real dominant culture to which one might assimilate. Everyone in Prava is marginal, from the expatriate writers to the mob bosses.

Shteyngart's novel does not end with Vladimir returning happily to the bosom of Eastern Europe to live out his days; rather, the novel once again plays with the tropes of earlier Americanization novels, in which the characters assimilate, in some degree or another, to American culture. The changes wrought in the postmodern global community are such that borders are flexible and a person's statehood un- 
stable, allowing Vladimir to return to America whenever he chooses. Vladimir returns to the United States when his life is threatened by the mob boss he works for; he therefore repatriates, but this time he is relieved to immigrate in order to escape the instability of the new Eastern Europe.

Just as his initial entry to America engendered nostalgia for his lost home, his visit to Eastern Europe rekindles feelings of nostalgia once he returns to America. But after his brief time abroad, the nostalgia he experiences is for his time in Prava, not for his time in the Soviet Union. The trip to Prava was, indeed, a repatriation to a place partly constructed out of Vladimir's own fantasies of an expatriate lifestyle, based largely on romantic and literary notions of pre-war Paris. After assimilating to the life of the American abroad, he is then rudely shocked when he returns to the United States only to find a bland, comfortable life, in which he dreams constantly of his time in Prava.

The novel ends five years after it began. Vladimir is thirty. He is a lawyer, having gone to law school upon his return from Prava. He is married to Morgan, his Midwestern American girlfriend, whom he met in Stolovaya, and they are expecting a baby. They live in a middle-class suburb of Cleveland, and Vladimir hopes to become a partner in his father-in-law's firm. The suburban perfection of Vladimir's existence at the end of the novel is a sharp contrast to the beginning of the novel, when Vladimir is living in the urban disarray of New York City and working for the Emma Lazarus Center. His Midwestern existence also contrasts nicely with the decaying European Prava. In New York and Prava Vladimir was a displaced person living among displaced persons, but in the Midwest he is a displaced person living among "authentic" Americans. He has, in a sense, upgraded from an "amateur assimilationist" or "beta immigrant" to a "real" assimilated American.

The problem is, however, that he is trapped in a different kind of anti-memory: a Jamesonian reconstruction of a modern-day Levittown, a hopeful place for young families to begin their lives amid the new luxuries of the day. Instead of reveling in the pleasures of dishwashers and post-war plastics, however, Vladimir finds himself driving a sports utility vehicle and answering a car phone (448). These accoutrements of the American bourgeois announce to the reader, in strictly realist terms that contrast dramatically with his exaggerated European experience, that Vladimir has arrived. Nevertheless, the narrator tells us that Vladimir dreams, "at least once a week," of returning to his old Prava-style life: "Vladimir locks his office door, closes his eyes, and dreams of . . . A scheme! A provocation! Pyramids! Turbo props! The Frankfurt exchange! The old Girshkin something for nothing!" (451). Vladimir misses the excitement of his marginal livelihood in Prava, which seems to him, from the distant vantage point of the future, to have been a romantic, marvelous, and wholly unreal period.

The nostalgic's ambivalence about his current life is captured in the novel's final paragraphs by the symbol of the impending Girshkin - the child that Vladimir and his American wife await. Vladimir imagines the child to be a boy, but one entirely unlike Vladimir, a son growing up "adrift in a private world of electronic goblins and quiet sexual urges. Properly insulated from the elements by stucco and storm windows. Serious and a bit dull, but beset by no illness, free of the fear and 
madness of Vladimir's Eastern lands. In cahoots with his mother. A partial stranger to his father" (452).

Shteyngart describes Vladimir's son as privileged in a way that Vladimir was not, growing up in politically stable environment and thereby aligned naturally with Morgan. His description underscores the consistent alienation that Vladimir feels in America, where he is forever destined to be marginalized, even within his own nuclear family unit. His accent, his name, and the fact that he was once the criminal ruler of Prava's underclass keep him on the edges of American respectability. As long as he remains marginalized, as long as he remains an outsider, as long as he resists assimilation, he remains nostalgic.

In the sense that he is forever caught between America and Eastern Europe, Vladimir is Shteyngart's porte-parole, his fictional self. Shteyngart also lays claim to a feeling of alienation and ambivalence, one that feeds his nostalgia for his Russian childhood. In his essay "The Mother Tongue Between Two Slices of Rye" he writes that, on a trip back to visit Russia, he welcomes his physical exile from American comfort:

I have fallen off the edges of the known universe, with its Palm Pilots, obnoxious vintage shops, and sleek French-Caribbean Brooklyn bistros .... I repeat [words in English] to my phantom New York friend, trying to regain my American balance, the sense that rationalism, psychiatry, and a few sour-apple martinis can take care of the past .... But it's no use. (1-2)

His catalogue of American accoutrements-from the technological and commercial to the palliative - is meant to be satiric, even derisive. As the reader realizes that Shteyngart participates in or partakes of all that America has to offer in the way of psychoanalysis or culinary exotica, one also realizes that Shteyngart derides these luxuries for being somewhat ridiculous_-at least they are made so by the comparison of American capitalist excess to Spartan post-Soviet life, which is sustained by the Russian language, a tongue most useful for "ordering mushroom and barley soup, directing the cab driver to some forgotten grave, planning the putsch that will for once install an enlightened government" (2).

Returning to Russia offers an escape from that culture and a return to the familiar-even if formerly oppressive-homeland. When he returns to Russia, it is as if he returns to the safety of childhood: "When I return to Russia, my birthplace, I cannot sleep for days. The Russian language swaddles me . . . Every old woman cooing to her grandson is my dead grandmother. Every glum and purposeful man picking up his wife from work in a dusty Volga sedan is my father" (1). This recreation of childhood memories, this revivification of dead grandmothers, is of course nostalgia writ large, and it indicates the inability or unwillingness of the new American writer to jettison his former identity and replace it with a recognizably American one.

The freedom to come and go between his old and new nations derails his efforts to assimilate fully into American culture. He can return, he can speak his mother tongue, he can indulge his nostalgic fantasies and memories by reclaiming his past experience. Shteyngart uses language in his essay (and in his novel) to 
point up this antiassimilationist stance. He sprinkles his English with Russian and with puns and rhymes, playing with the words in true Nabokovian fashion, as illustrated by the use of the word "rye" (which is meant, the reader believes, to also mean "wry") in the title of his essay. His nostalgia can never be "cured," least of all by the pressure to Americanize; in the new immigrant literature, assimilation is not rendered as an absolute, inevitable outcome of immigration but as part of a larger, global condition, one that plagues the traveler or the expatriate just as it does the immigrant. Caught between the local and the universal, between the personal and the collective, the immigrant cannot erase his identity and replace it with an American one; rather, he is always looking forward to the next step, the next level of achievement or dissatisfaction, the next country or pyramid scheme, the new city or the new baby. As Boym suggests, progress exacerbated nostalgia, so it precludes assimilation. The new narrative of Americanization, then, needs a new name. The twenty-first century will surely invent one.

\section{Works Cited}

Antin, Mary. The Promised Land. 1912. New York: Penguin Books, 1997.

Appadurai, Arjun. Modernity at Large: Cultural Dimensions of Globalization. Minneapolis: University of Minnesota Press, 1996.

Bezmozgis, David. Natasha: And Other Stories. New York: Farrar, Strauss, and Giroux, 2004.

Boelhower, William. Immigrant Autobiography in the United States: Four Versions of the Italian-American Self. Verona: Essedue Edizioni, 1982.

Boym, Svetlana. The Future of Nostalgia. New York: Basic Books, 2001.

Dames, Nicholas. Amnesiac Selves: Nostalgia, Forgetting, and British Fiction, 1810-1870. Oxford: Oxford University Press, 2001.

Daniels, Roger. Coming to America: A History of Immigration and Ethnicity in American Life. New York: Harper Collins, 1990.

Jameson, Fredric. "Nostalgia for the Present." South Atlantic Quarterly 88.2 (1989): 517537.

Shteyngart, Gary. "The Mother Tongue Between Two Slices of Rye." The Threepenny Review 97 (Spring 2004) <http://www.threepennyreview.com/samples/ shteyngart_sp04.html>.

-. The Russian Debutante's Handbook. New York: Riverhead Books, 2002.

Vapnyar, Lara. There Are Jews in My House. New York: Pantheon, 2003. 